\title{
Методичний підхід до обґрунтування вартості життєвого циклу носіїв спроможностей Збройних сил України (організаційних структур та органів управління)
}

\author{
Олег Семененко ${ }^{1}$ А; І Ірина Чернишова 2 А; Петро Онофрійчук ${ }^{3}$ А; \\ Іван Мотрунич 4 в; Костянтин Харитонов ${ }^{5}$ в; Роман Демчук 6 C \\ А Центральний науково-дослідний інститут Збройних Сил України, пр-кт Повітрофлотський 28, м. Київ, 03049, Україна

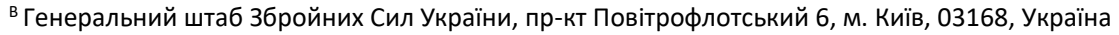 \\ с Національний університет оборони України імені Івана Черняховського, пр-кт Повітрофлотський 28, м. Київ, 03049, Україна
}

Received: July 20, 2021 | Revised: August 23, 2021 | Accepted: August 31, 2021

DOI: $10.33445 /$ sds.2021.11.4.2

\begin{abstract}
Анотація
Зміни характеру сучасних воєнних конфліктів, збільшення зовнішніх загроз, зміни економічних та військово-технічних умов розвитку України впливають на діапазон та зміст завдань, до виконання яких залучаються Збройних Сил (3С) України. Зазначене обумовлює пошук нових підходів до планування розвитку ЗС України та створюють передумови для необхідності удосконалення існуючої системи оборонного планування в Україні взагалі. Одним зі шляхів забезпечення ефективного функціонування сучасної системи оборонного планування України вважається запровадження методу планування на основі спроможностей та обґрунтування витрат з використанням поняття вартості життєвого циклу. У статті авторами запропонований методичний підхід до обґрунтування вартості життєвого циклу носіїв спроможностей ЗС України (організаційних структур та органів управління). Обгрунтування вартості організаційних структур та органів управління 3С України із застосування поняття вартості їх життєвого циклу надасть можливість підвищити достовірність розрахунків щодо очікуваного результату заходів розвитку спроможностей ЗС України та обсягів необхідних фінансових ресурсів на потреби їх розвитку. Застосовувати даний підхід пропонується спеціалістам Міністерства оборони України та Генерального штабу ЗС України під час прийняття рішень щодо формування варіантів переліку організаційних структур та органів управління 3С України та визначення тривалості їх існування. Запропонований методичний підхід обґрунтування вартості життвого циклу носіїв спроможностей ЗС України може бути основою для вирішення завдань оборонного планування та управління оборонними ресурсами щодо: визначення вартості окремого носія спроможності ЗС України; визначення вартості стадій життєвого циклу носія спроможності ЗС України; визначення повної прогнозованої вартості життєвого циклу носія спроможності ЗС України з метою оцінювання доцільності їх створення, подальшого розвитку, розформування або переформування.
\end{abstract}

Ключові слова: життєвий цикл, витрати, спроможність, ресурси, планування.

\section{Постановка проблеми}

Зміни характеру сучасних воєнних конфліктів, діапазону та змісту завдань, до виконання яких залучаються Збройних Сил
(3С) України, збільшення зовнішніх загроз, зміни економічних та військово-технічних умов розвитку України вимагають пошуку

\footnotetext{
${ }^{1}$ Corresponding author: д. військ. н., с.н.с., начальник відділу, e-mail: aosemenenko@ukr.net, ORCID: 0000-0001-6477-3414

2 к. воен. н., с.н.с., e-mail: aosemenenko@ukr.net, ORCID: 0000-0002-5958-7059

${ }^{3}$ кандидат економічних наук, старший науковий співробітник, e-mail: aosemenenko@ukr.net, ORCID: 0000-0003-2203-5282

${ }^{4}$ e-mail: aosemenenko@ukr.net, ORCID: 0000-0001-6117-1784

${ }^{5}$ здобувач наукового ступеня, e-mail: kvharitonov.1212@gmail.com, ORCID: 0000-0002-5236-0556

${ }^{6}$ e-mail: aosemenenko@ukr.net, ORCID: 0000-0003-0354-0371
} 
нових підходів до планування розвитку 3С України та створюють передумови для необхідності удосконалення існуючої системи оборонного планування в Україні взагалі.

Одним зі шляхів забезпечення ефективного функціонування сучасної системи оборонного планування України вважається запровадження в нього методу планування на основі спроможностей. Актуалізація питання нарощування спроможностей ЗС України шляхом створення нових та реформування існуючих організаційних структур (з'єднань, частин підрозділів, військових навчальних закладів, установ, організацій тощо) та органів управління ЗС України, а також планування процесу їх життєдіяльності (функціонування) створює передумови до підвищення ефективності витрачання необхідних для цього державних коштів.

Період повного циклу існування військових організмів досить тривалий, тому виникають такі проблеми, як: невідповідність їх організаційно-штатної структури новим завданням; старіння озброєння та військової техніки (ОВТ); зниження показників бойової ефективності ОВТ, а також показників рівня бойової готовності та рівня боєздатності цих військових організмів тощо.
Однією 3 неодмінних умов вирішення більшості проблем оборонного значення $\epsilon$ чітке розуміння та урахування економічного аспекту їх подолання. У сучасних умовах розвитку ЗС України та держави в цілому не можна ефективно вирішувати оборонні проблеми, не маючи: обґрунтованих розрахунків щодо кількісних та вартісних показників необхідних ресурсів для їх розв'язання; раціональної структури розподілу цих ресурсів за складовими програм та планів досягнення кінцевої мети вирішення існуючої проблеми; науково обґрунтованих підходів до ефективного використання ресурсів протягом періоду вирішення досліджуваної проблеми оборонного значення.

Трансформація системи оборонного планування із урахуванням застосування принципів методу планування на основі спроможностей формує потребу у пошуку нових підходів до визначення та обґрунтування вартісних показників необхідних ресурсів на потреби розвитку спроможностей окремих організаційних структур і органів управління ЗС України та 3 С України в цілому, які 6 надавали можливість ефективно управляти оборонними ресурсами під час формування та виконання програм та планів розвитку спроможностей ЗС України.

\section{Аналіз останніх досліджень та публікацій}

Останнім часом під час обгрунтування витрат використовують поняття вартості життєвого циклу (Life Cycle Costing). Нині, в Україні під час публічних закупівель товарів та послуг в бюджетній сфері застосовується методика визначення вартості життєвого циклу закупівлі. Ця методика розроблена Мінекономіки у 2020 році [1], і $€$ основою здійснення закупівель товарів та послуг. Аналогічні методики $€$ основою публічних закупівель і у Європейському Союзі [2]. В Міністерстві оборони розроблені методичні рекомендації 3 фінансово-економічного обґрунтування вартості повного життєвого циклу спроможностей 3 урахуванням принципів та стандартів НАТО [3]. Крім того, існують національні стандарти, міжнародні практики та методи, які описують вартість життєвого циклу [4-15].

Детальний аналіз зазначених документів та існуючих підходів до обґрунтування вартості життєвого циклу носіїв спроможностей ЗС України та інших держав засвідчив, що сутність методик обгрунтування вартості житєвого циклу полягає в тому, що пропозиції оцінюються не лише за ціною товару (послуги), а й за вартістю його (іiі) подальшої експлуатації (використання). Витрати на той чи інший товар (послугу) - особливо, якщо йдеться про техніку - не завершуються на його купівлі. Тобто, у перспективі на роки більш вигідним 
придбанням часто виявляються дорожчі, але якісніші товари (послуги). Отже, закупівля на основі показника (критерію) вартості життєвого циклу надає можливість проводити більш ефективні закупівлі та заощаджувати кошти в довготривалому періоді.

Отже, обґрунтування організаційних структур та органів управління ЗС України із застосування поняття вартості їх життєвого циклу надасть можливість підвищити достовірність розрахунків щодо очікуваного результату заходів розвитку спроможностей 3 України та обсягів необхідних фінансових ресурсів на потреби їх розвитку.

\section{Постановка завдання}

Тому мета статті передбачає представити методичний підхід до обґрунтування вартості життєвого циклу носіїв спроможностей 3 С
України (організаційних структур та органів управління 3С).

\section{Виклад основного матеріалу}

Згідно Методичних рекомендацій 3 фінансово-економічного обгрунтування вартості повного життєвого циклу спроможностей з урахуванням принципів та стандартів НАТО, [2] визначено, що:

життєим циклом спроможності - $\epsilon$ сукупність стадій створення, впровадження та використання спроможності в інтервалі часу, що починається з моменту розробки концепції, визначення технічних інших вимог до спроможності, i закінчується виведенням її із експлуатації;

вартістю життєвого циклу спроможності $\epsilon-$ сумарні витрати трудових, матеріальних i фінансових ресурсів в їх грошовому вираженні пов'язані із реалізацією життєвого циклу спроможності;

стадіями життєвого циклу спроможності - $\epsilon$ частина життєвого циклу, що виокремлюється за ознаками характерних для неї явищ, процесів (робіт) і кінцевих результатів.

Пропонований методичний підхід передбачає, що під носіями спроможностей розуміються організаційні структури (з'єднання, частини, підрозділи, військові навчальні заклади, установи, організації) та органи управління ЗС України. Даний підхід не призначений для оцінювання вартості життвого циклу зразків, систем та комплексів ОВТ тощо.

В Методичному підході використано терміни та понятяя закладені в існуючих національних стандартах, міжнародних практиках та методах, описаних відповідними стандартами та публікаціями [1-15].

Методичний підхід обгрунтування вартості життєвого циклу носіїв спроможностей 3 С України (далі - Підхід) призначений для проведення розрахунків прогнозованих показників обсягів фінансових витрат життєвого циклу будь-якої організаційної структури або органу управління ЗС України за стадіями життєвого циклу та за повний його період.

Застосування зазначеного Підходу передбачається в органах військового управління спеціалістами за напрямом оборонного планування та управління оборонними ресурсами з метою підвищення: обґрунтованості управлінських рішень щодо планування розвитку носіїв спроможностей ЗС України; ефективності витрачання державних коштів на розвиток носіїв спроможностей; достовірності очікуваних результатів розвитку носіїв спроможностей ЗС України.

Під життєвим циклом розуміється період від початку створення носія спроможності до моменту здавання до архіву документів розформованої організаційної структури (органу управління). Якщо носій спроможності зазнає переформування, то останньою стадією життвого циклу $\epsilon$ період його переформування й відповідно ця стадія $\epsilon$ першою для життєвого циклу нового носія, який створюється на його основі. Схематично це зображено на рис. 1. 


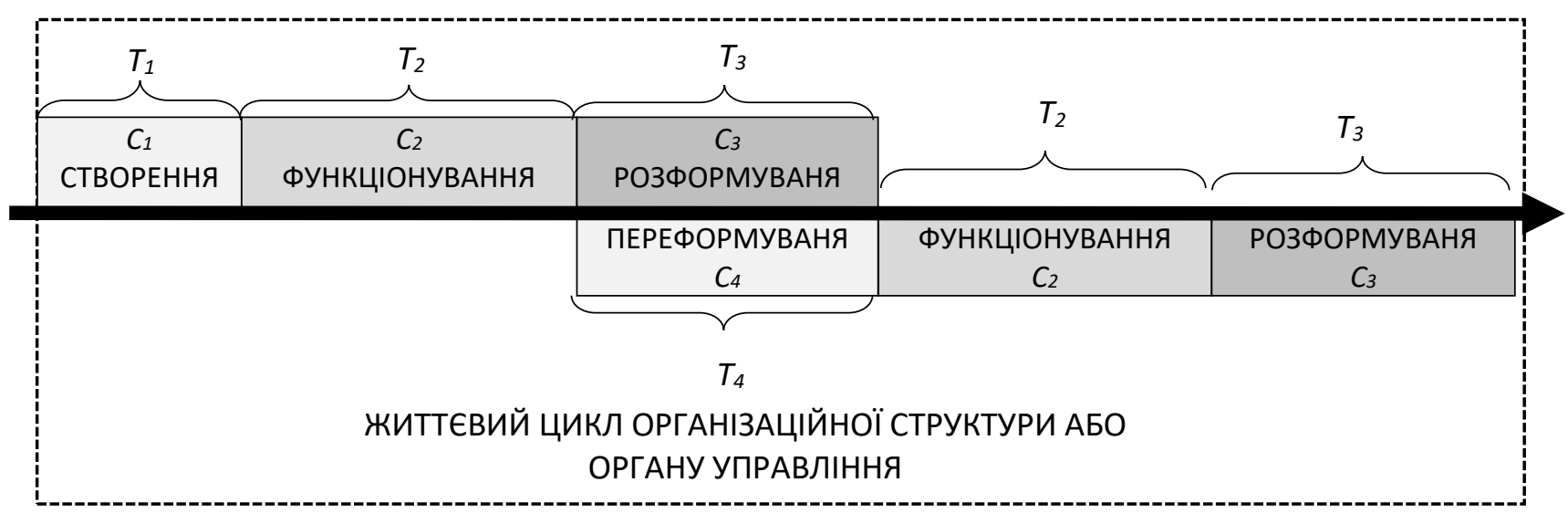

Рис. 1 - Взаємозв'язок стадій життєвого циклу носіїв спроможностей (організаційних структур або органів управління) Збройних Сил України

Отже, тривалість життєвого циклу ( $T_{\text {жц }}$ носіїв спроможностей ЗС України може містити такі стадії: період створення та становлення $\left(T_{1}\right)$ або переформування $\left(T_{4}\right)$; період функціонування за призначенням $\left(T_{2}\right)$; період розформування $\left(T_{3}\right)$ або переформування $\left(T_{4}\right)$. Тобто можливі три варіанти тривалості життєвого циклу організаційних структур або органів управління ЗС України:

$$
\begin{aligned}
& \text { варіант } 1-T_{\text {жц }}=T_{1}+T_{2}+T_{3} \text {; } \\
& \text { варіант } 2-T_{\text {жц }}=T_{1}+T_{2}+T_{4} \text {; } \\
& \text { варіант } 3-T_{\text {жц }}=T_{4}+T_{2}+T_{3} \text {. }
\end{aligned}
$$

Відповідно вартість життєвого циклу $\left(C_{ж ц}\right)$ носіїв спроможностей ЗС України може розраховуватися таким чином:

$$
\begin{aligned}
& \text { для варіанту } 1-C_{\text {жц }}=C_{1}+C_{2}+C_{3} \text {; } \\
& \text { для варіанту } 2-C_{ж ц ~}=C_{1}+C_{2}+C_{4} \text {; } \\
& \text { для варіанту } 3-C_{Ж ц}=C_{4}+C_{2}+C_{3} \text {, }
\end{aligned}
$$

де $C_{1}$ - вартість створення носія спроможності;

$C_{2}$ - вартість функціонування носія спроможності за призначенням;

$C_{3}$ - вартість переформування носія спроможності;

$C_{4}$ - вартість розформування носія спроможності.

Оцінювання вартості життєвого циклу носіїв спроможностей базується на показниках обсягів витрат різнорідних ресурсів для певної організаційної структури (органу управління) у вартісному еквіваленті на початок будь-якої стадії життєвого циклу, а також під час оцінювання враховано динаміку (зміну) вартості носія спроможності протягом тривалості періоду стадії. Метою такого оцінювання $€$ визначення, вибір та обґрунтування раціональних показників повної вартості життєвого циклу носіїв спроможностей за стадіями життєвого циклу, а також підвищення обґрунтованості управлінських рішень щодо планування та використання фінансових ресурсів для забезпечення життєвого циклу носіїв спроможностей зС України.

Необхідними умовами для застосування Методики обґрунтування вартості життєвого циклу носіїв спроможностей ЗС України є такі.

1. Підтримання та розвиток носія спроможності ЗС України, забезпечується своєчасним виконанням комплексу запланованих заходів фінансування 3 визначеними натуральними показниками за базовими компонентами носія спроможності. Базовими компонентами носія спроможності $\epsilon$ : особовий склад, озброєння та військова техніка (ОВТ), військова інфраструктура (Віф), витратні матеріально-технічні засоби (Мт3).

2. Натуральними показниками за базовими компонентами носіїв спроможностей 
(організаційних структур або органів управління ЗС України) є: кількість особового складу; кількість зразків ОВТ за групами та видами; кількість об'єктів інфраструктури; обсяг та кількість витратних Мт3 (обсяг ПММ, кількість боєкомплектів, тощо).

3. Фінансування носіїв спроможностей (організаційної структури або органу управління ЗС України) відбувається за основними напрямами витрат. За кожним напрямом витрат (це $і$-ті складові), які необхідно профінансувати за певним переліком заходів (це j-ті елементи). Тобто, кожна $i$-та складова носія спроможності організаційної структури або органу управління ЗС України містить $j$-ті елементи (заходи фінансування).

4. Для забезпечення одиниці натурального показника кожного j-го елемента (заходу фінансування) відповідної $i$-ї складової необхідно певну кількість фінансових ресурсів (коштів) $c_{j i}{ }^{0}$, тобто для досягнення натурального показника необхідного (очікуваного) результату $W^{\text {н }}$ треба витратити певну кількість ресурсів у грошовому еквіваленті $C^{H}$.

Загальна структурна схема Методичного підходу обґрунтування вартості життєвого циклу носіїв спроможностей ЗС України наведена на рис. 2.

Ця схема містить чотири взаємопов'язані етапи, кожен з яких має чітко визначену блочно-ієрархічну побудову та передбачає проведення певних математичних розрахунків та аналітичних операцій.

На першому етапі формуються вихідні дані та показники, які характеризують організаційну структуру або орган управління 3С України (носій спроможності) та його життєвий цикл. Визначаються натуральні показники за базовими складовими носія спроможності. Тобто кількість особового складу, ОВТ та об'єктів інфраструктури, а також запасів МтЗ для кожного носія спроможності:

$$
W^{\mathrm{H}}=\sum_{i=1}^{4} W_{\mathrm{i}}^{\mathrm{H}}=\sum_{i=1}^{4} \sum_{j} \quad W_{j \mathrm{i}}^{\mathrm{H}},
$$

де $W^{\text {н }}$ - загальна необхідна кількість особового складу, ОВТ, об'єктів інфраструктури, витратних Мт3 для підтримання та розвитку організаційної структури або органу управління 3С України;

$W_{1}^{\mathrm{H}}, W_{2}^{\mathrm{H}}, W_{3}^{\mathrm{H}}, W_{4}^{\mathrm{H}}$ - необхідна кількість особового складу, ОВТ, об'єктів інфраструктури, витратних Мт3 для організаційної структури або органу управління ЗС України;

$W_{j \mathrm{i}}^{\mathrm{H}}$ - необхідна кількість особового складу, ОВТ, об'єктів інфраструктури, витратних Мт3 за кожним ј-им елементом (заходом фінансування) i-ої складової (напрямом витрат).

Зазначені базові компоненти носіїв спроможностей обрано з тієї точки зору, що боєздатність військ (сил) залежить від укомплектованості 3С України особовим складом, рівня його навченості, втрат та можливості їх компенсування (поповнення), а також від рівня забезпеченості кожного носія спроможності матеріально-технічними засобами та озброєнням і військовою технікою. Крім того, треба враховувати, що фінансування організаційної структури або органу управління ЗС України відбувається за основними напрямами витрат: особовий склад (персонал), озброєння та військова техніка, інфраструктура та експлуатаційні витрати (це $i$-і складові). При цьому за кожним напрямом фінансування існує певний перелік заходів (це j-і елементи). 


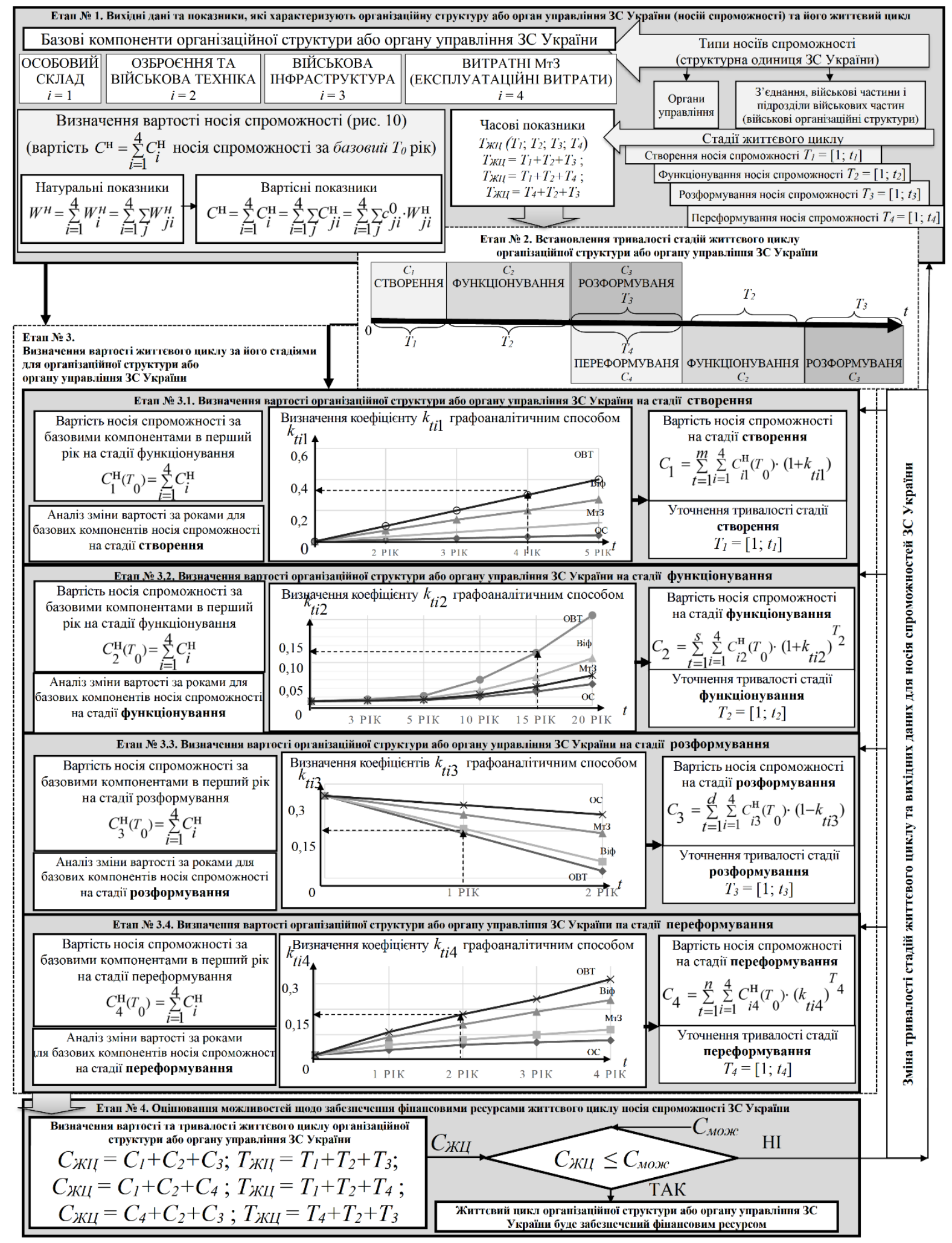

Рис. 2 - Загальна структурна схема Методичного підходу до обгрунтування вартості життвого циклу носіїв спроможностей (організаційних структур або органів управління) Збройних Сил України

Тобто, кожна і-та складова (напрям фінансування) організаційної структури або органу управління ЗС України містить $j$-і елементи (заходи фінансування). Схематично це представлено на рис. 3. 


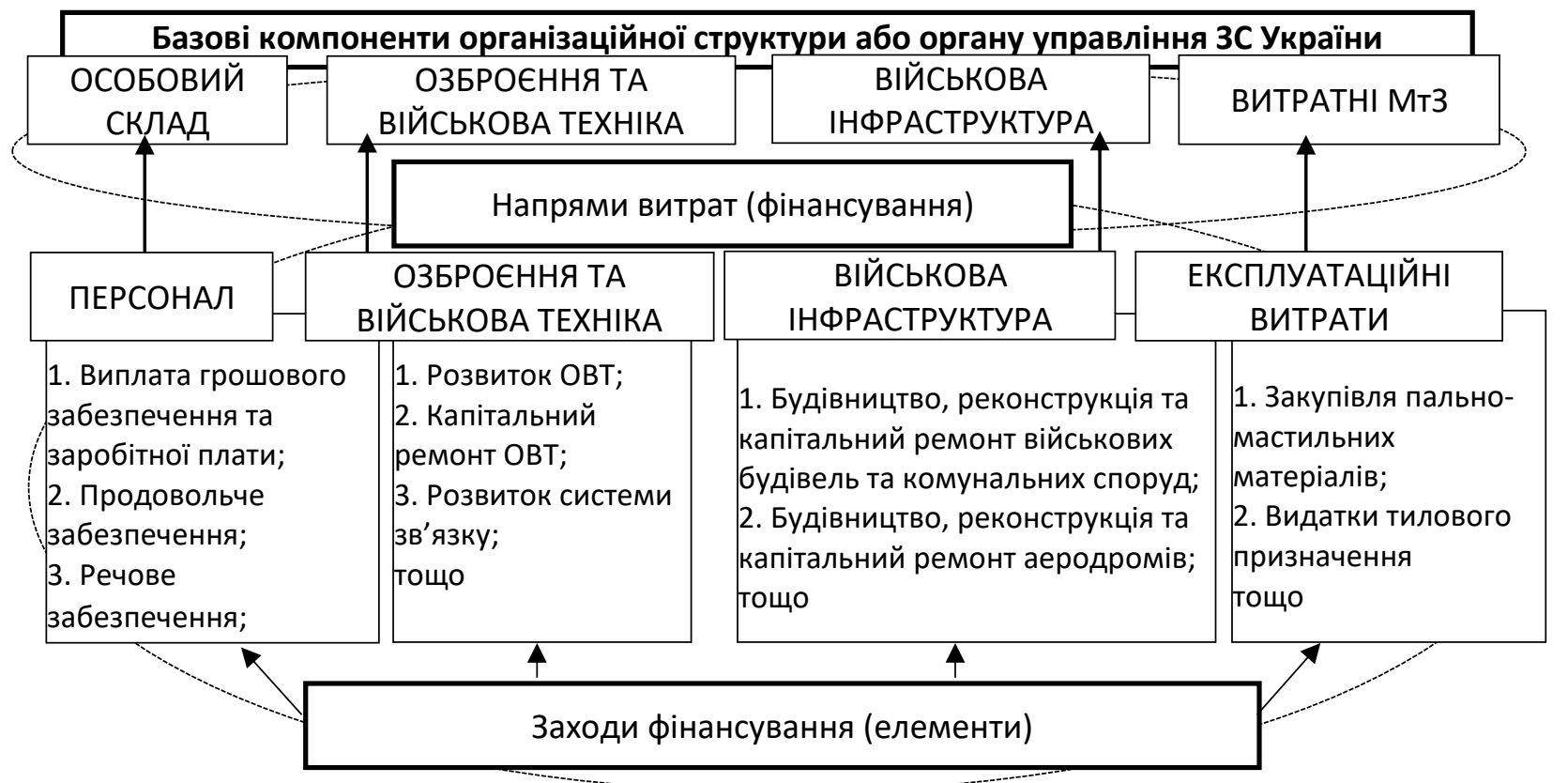

Рис. 3 - Взаємозв'язок базових компонентів носіїв спроможностей (організаційної структури або органу управління) Збройних Сил України та основних напрямів їх фінансування

Із застосуванням порядку визначення вартості носія спроможності [16], який представлений окремо (рис.4), встановлюється вартість організаційної структури або органу управління ЗС України (носія спроможності) на рік:

$$
C^{\mathrm{H}}=\sum_{i=1}^{4} C_{i}^{\mathrm{H}}=\sum_{i=1}^{4} \sum_{j} C_{j i}^{\mathrm{H}}=\sum_{i=1}^{4} \sum_{j}^{0} c_{j i}^{0} \cdot W_{j i}^{\mathrm{H}},
$$

де $C^{H}-$ необхідний обсяг фінансових ресурсів для підтримання та розвитку організаційної структури або органу управління ЗС України;

$C_{i}^{H}$ - необхідний обсяг фінансових ресурсів для i-ої складової (напряму витрат) організаційної структури або органу управління 3 У України, що надасть можливість підтримувати та розвивати організаційну структуру або орган управління ЗС України;

$\mathrm{C}_{j \mathrm{i}}^{\mathrm{H}}$ - необхідний обсяг фінансових ресурсів для $j$-го елемента $i$-ої складової, що надасть можливість підтримувати та розвивати організаційну структуру або орган управління
ЗС України;

$c_{j i}^{0}$ - вартість 1 од. натурального показника за j-им елементом (заходом фінансування) $i$-ої складової.

На другому етапі попередньо визначається тривалість життєвого циклу носія спроможності $T_{ж ц}\left(T_{1} ; \quad T_{2} ; \quad T_{3} ; T_{4}\right)$ та встановлюються межі кожної стадії життєвого циклу: для першої стадія життєвого циклу (створення), $T_{1}=\left[1 ; t_{1}\right]$ від 1 до $t_{1}$ років; для другої стадія життєвого циклу (функціонування), $T_{2}=\left[1 ; t_{2}\right]$ від 1 до $t_{2}$ років; для третьої стадія життєвого циклу (розформування), $T_{3}=\left[1 ; t_{3}\right]$ від 1 до $t_{3}$ років; для четвертої стадія життєвого циклу (переформування), $T_{4}=\left[1 ; t_{4}\right]$ від 1 до $t_{4}$ років.

Третій етап передбачає визначення вартості життєвого циклу за його стадіями. Результатами розрахунків на цьому етапі $\epsilon$ вартість носія спроможності (організаційної структури або органу управління) за стадіями життєвого циклу. 


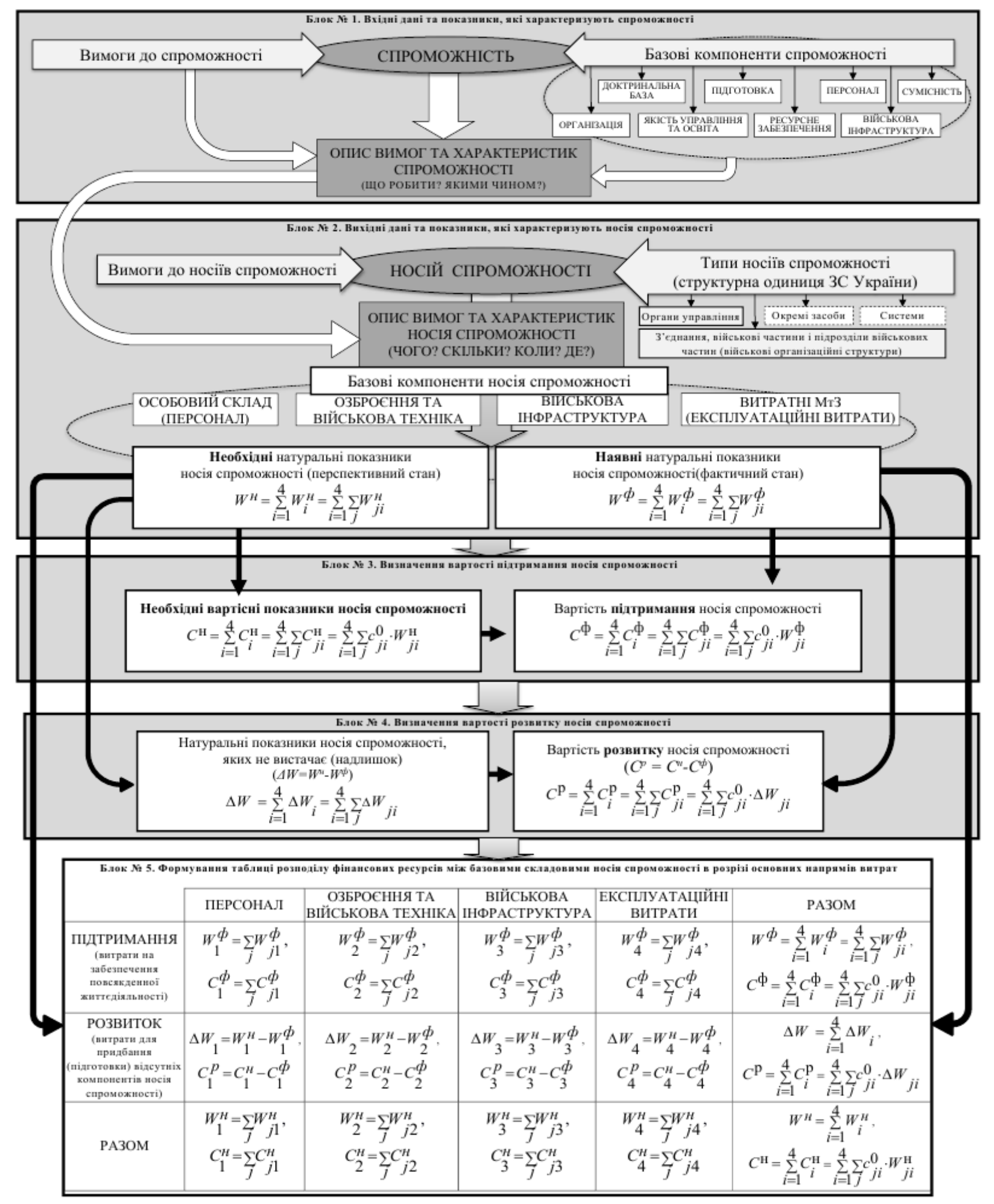

Рис. 4 - Порядок визначення вартості носія спроможності Збройних Сил України (організаційної структури або органу управління) на час $T_{0}$

Для стадії створення спочатку визначається вартість носія спроможності в перший рік на цій стадії $C_{1}^{\mathrm{H}}\left(\mathrm{T}_{0}\right)$ (базовий показник проведення розрахунків), яка розраховується згідно з формулою (1):

$$
C_{1}^{\mathrm{H}}\left(T_{0}\right)=\sum_{i=1}^{4} C_{i}^{\mathrm{H}}=\sum_{i=1}^{4} \sum C_{j i}^{\mathrm{H}}=\sum_{i=1}^{4} \sum_{j} c_{j i}^{0} \cdot W_{j i}^{\mathrm{H}} .
$$

Далі визначається загальна вартість організаційної структури або органу управління на стадії створення: 


$$
C_{1}=\sum_{t=1}^{m} \sum_{i=1}^{4} C_{i 1}^{\mathrm{H}}\left(T_{0}\right) \cdot\left(1+k_{t i 1}\right) .
$$

Для стадії функціонування, розрахунки відбуваються аналогічно до попередньої стадії життєвого циклу. Спочатку визначається вартість носія спроможності в перший рік на стадії функціонування $C_{2}^{\mathrm{H}}\left(\mathrm{T}_{0}\right)$ :

$$
C_{2}^{\mathrm{H}}\left(T_{0}\right)=\sum_{i=1}^{4} C_{i}^{\mathrm{H}}=\sum_{i=1}^{4} \sum_{j} C_{j i}^{\mathrm{H}}=\sum_{i=1}^{4} \sum_{j} c_{j i}^{0} \cdot W_{j i}^{\mathrm{H}} .
$$

Далі визначається загальна вартість організаційної структури або органу управління на стадії функціонування:

$$
C_{2}=\sum_{t=1}^{S} \sum_{i=1}^{4} C_{i 2}^{\mathrm{H}}\left(T_{0}\right) \cdot\left(1+k_{t i 2}\right)^{T} .
$$

Для стадії розформування. Спочатку визначається вартість носія спроможності в перший рік на стадії розформування $C_{3}^{\mathrm{H}}\left(\mathrm{T}_{0}\right)$ :

$$
C_{3}^{\mathrm{H}}\left(T_{0}\right)=\sum_{i=1}^{4} C_{i}^{\mathrm{H}}=\sum_{i=1}^{4} \sum_{j} C_{j i}^{\mathrm{H}}=\sum_{i=1}^{4} \sum_{j} c_{j i}^{0} \cdot W_{j i}^{\mathrm{H}} .
$$

Далі визначається загальна вартість організаційної структури або органу управління на стадії розформування:

$$
C_{3}=\sum_{t=1}^{d} \sum_{i=1}^{4} C_{i 3}^{\mathrm{H}}\left(T_{0}\right) \cdot\left(1-k_{t i 3}\right) \cdot
$$

Для стадії переформування. Спочатку визначається вартість носія спроможності в перший рік на стадії переформування $C_{4}^{\mathrm{H}}\left(T_{0}\right)$ :

$$
C_{4}^{\mathrm{H}}\left(T_{0}\right)=\sum_{i=1}^{4} C_{i}^{\mathrm{H}}=\sum_{i=1}^{4} \sum_{j} C_{j i}^{\mathrm{H}}=\sum_{i=1}^{4} \sum_{j} c_{j i}^{0} \cdot W_{j i}^{\mathrm{H}} .
$$

Далі визначається загальна вартість організаційної структури або органу управління на стадії функціонування:

$$
C_{4}=\sum_{t=1}^{n} \sum_{i=1}^{4} C_{i 4}^{\mathrm{H}}\left(T_{0}\right) \cdot\left(k_{t i 4}\right)^{T} .
$$

Також на цьому етапі необхідно

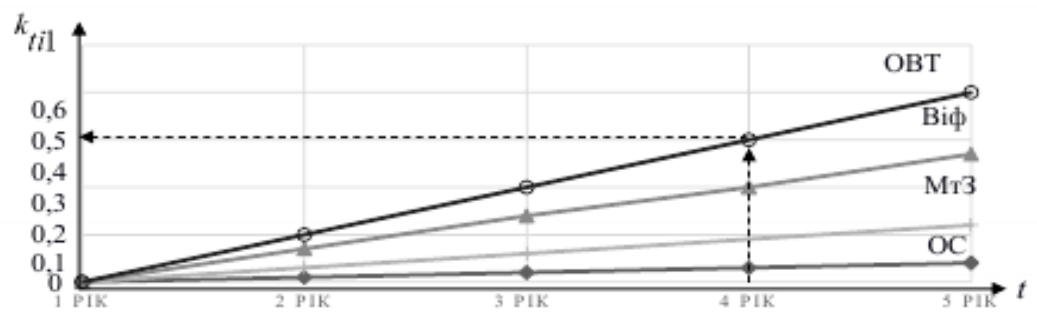

Рис. 5 - Номограма залежності коефіцієнтів динаміки вартості $k_{t i 1}$ базових компонентів носія спроможності Збройних Сил України від тривалості стадії життєвого циклу щодо його створення $T_{1}$ уточнювати тривалість кожної стадії життєвого циклу носія спроможності: $T_{1}=[1$; $\left.t_{1}\right] ; T_{2}=\left[1 ; t_{2}\right] ; T_{3}=\left[1 ; t_{3}\right] ; T_{4}=\left[1 ; t_{4}\right]$.

Усі коефіцієнти динаміки вартості у часі повинні визначатися на основі наявної статистичної інформації щодо зміни вартості кожної із стадій життєвого циклу носія спроможності методами регресійного та кореляційного аналізу, емпірично або шляхом проведення експертного опитування. Величина коефіцієнтів динаміки вартості стадії життєого циклу носія спроможності залежать від виду (типу) носія спроможності, а також впливу зовнішніх та внутрішніх факторів на різних стадіях життєвого циклу носія спроможності (організаційної структуру або органу управління 3С України). Для підвищення оперативності проведення розрахунків вартісних показників життєвого циклу носіїв спроможностей запропоновано вплив коефіцієнтів динаміки вартості носія спроможності за кожною стадією життєвого циклу розраховувати графічно за допомогою завчасно розроблених номограм оцінювання коефіцієнтів динаміки вартості стадій життєвого циклу носіїв спроможностей 3 С України для кожного базового елемента носія спроможностей.

Приклади формування номограм коефіцієнтів динаміки вартості на відповідній стадії життєвого циклу для типового військового формування (типу омбр) за базовими елементами: ОВТ, ОС (персонал), Мт3 та Віф наведено на рис.5, рис. 6, рис. 7, рис.8. Запропонований варіант діапазону зміни коефіцієнтів динаміки вартості носіїв спроможності ЗС України за базовими елементами кожного носія відповідно до стадій життєвого циклу наведено у табл. 1. 


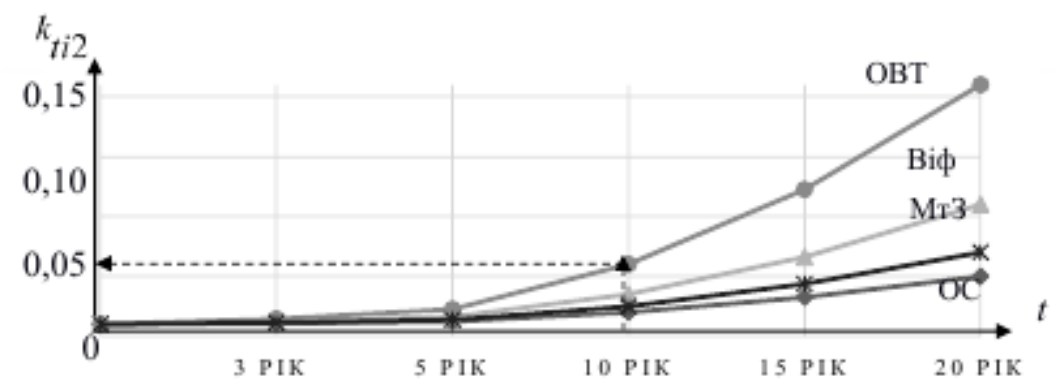

Рис. 6 - Номограма залежності коефіцієнтів динаміки вартості $k_{t i 2}$ базових компонентів носія спроможності Збройних Сил України від тривалості стадії життєвого циклу щодо його функціонування $T_{2}$.

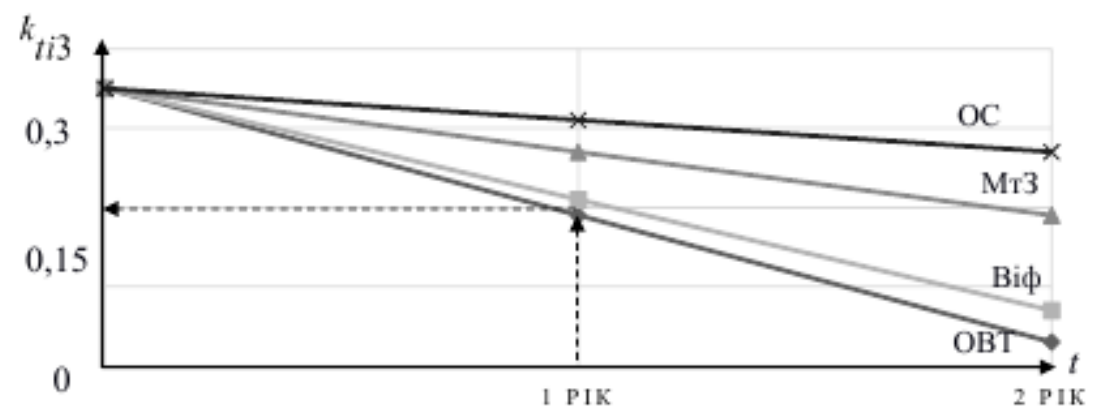

Рис. 7 - Номограма залежності коефіцієнтів динаміки вартості $k_{t i 3}$ базових компонентів носія спроможності Збройних Сил України від тривалості стадії життєвого циклу щодо його розформування $T_{3}$

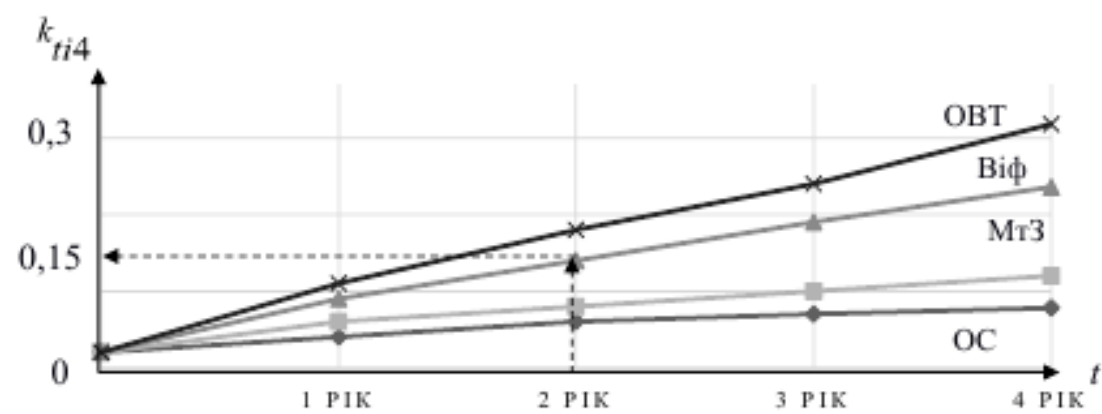

Рис. 8 - Номограма залежності коефіцієнтів динаміки вартості $k_{t i 4}$ базових компонентів носія спроможності Збройних Сил України від тривалості стадії життєвого циклу щодо його переформування $T_{4}$.

Таблиця 1 - Коефіцієнти динаміки вартості за базовими компонентами для стадій життєвого циклу організаційної структури або органу управління 3бройних Сил України

\begin{tabular}{|c|c|c|c|c|}
\hline ЖИТТЕВОГО & $\begin{array}{c}\text { ОСОБОСВИЙ } \\
\text { СКЛАД } \\
\text { (ПЕРСОНАЛ) } \\
1\end{array}$ & $\begin{array}{c}\text { ОЗБРОЄННЯ ТА } \\
\text { ВІЙСЬКОВА } \\
\text { ТЕХНІКА (ОВТ) } \\
2\end{array}$ & $\begin{array}{c}\text { ВІЙСЬКОВА } \\
\text { ІНФРАСТРУКТУРА } \\
\text { (Віф) } \\
3\end{array}$ & $\begin{array}{c}\text { ЕКСПЛУАТАЦІЙНІ } \\
\text { ВИТРАТИ } \\
\text { (МтЗ) } \\
4\end{array}$ \\
\hline Створення $\left(k_{t i 1}\right)$ & $0,1 \leq \mathrm{k}_{11} \leq 0,2$ & $0,5 \leq k_{21} \leq 0,6$ & $0,2 \leq k_{31} \leq 0,3$ & $0,2 \leq \mathrm{k}_{41} \leq 0,3$ \\
\hline Функціонування $\left(k_{t i 2}\right)$ & $0,05 \leq k_{12} \leq 0,1$ & $0,1 \leq \mathrm{k}_{22} \leq 0,15$ & $0,05 \leq k_{32} \leq 0,1$ & $0,05 \leq k_{42} \leq 0,1$ \\
\hline Розформування $\left(k_{t i 3}\right)$ & $0,05 \leq k_{13} \leq 0,1$ & $0,25 \leq k_{23} \leq 0,3$ & $0,1 \leq k_{33} \leq 0,15$ & $0,1 \leq k_{43} \leq 0,15$ \\
\hline Переформування $\left(k_{t i 4}\right)$ & $0,05 \leq k_{14} \leq 0,1$ & $0,25 \leq k_{24} \leq 0,3$ & $0,1 \leq k_{34} \leq 0,15$ & $0,1 \leq \mathrm{k}_{44} \leq 0,15$ \\
\hline
\end{tabular}


Встановлені коефіцієнти $k_{t \mathrm{i} 1}, k_{t \mathrm{i} 2}, k_{t \mathrm{i} 3}, k_{t \mathrm{i} 4}$ динаміки вартості за роками базових компонентів організаційної структури або органу управління ЗС України на відповідній стадії життєвого циклу визначаються графоаналітичним способом за допомогою завчасно сформованих номограм оцінювання коефіцієнтів динаміки вартості за роками стадій життєвого циклу носія спроможності для базових його компонентів (рис. 5, рис. 6, рис. 7, рис. 8).

На рис. 5 наведено номограму залежності коефіцієнтів динаміки вартості $k_{t \mathrm{i} 1}$ базових компонентів носія спроможності від тривалості стадії життєвого циклу щодо створення цього носія спроможності. Так як у більшості випадків стадія створення носія спроможності не перевищує 10-20\% його повного життєвого циклу, тому динаміку вартості на цій стадії для більшості носіїв спроможностей ЗС України можна описати лінійною функцією (рис. 5). Коефіцієнт $k_{t i 1}$ характеризує зміну (динаміку) вартості життєвого циклу базових компонентів носія спроможності ЗС України на стадії створення залежно від тривалості цієї стадії $T_{1}$.

Номограму оцінювання коефіцієнту динаміки вартості життєвого циклу базових компонентів носія спроможності ЗС України $k_{t \mathrm{i} 2}$ на стадії життєвого циклу щодо його функціонування залежно від ії тривалості представлено на рис. 6. Результати досліджень показують, що тривалість стадії утримання носія спроможності $€$ найбільшою (до 90\% життєвого циклу). Тому урахування фактору часу під час розрахунку вартості життєвого циклу носія спроможності на стадії утримання (функціонування) має нелінійний характер, та може бути описано степеневою функцією, велична степені якої залежить від приналежності до того чи іншого базового компонента носія спроможності (OC, ОВТ, Мт3, Віф) (рис. 2). Коефіцієнт $k_{t i 2}$ відображає зміну (динаміку) вартості життєвого циклу базових компонентів носія спроможності України на стадії функціонування (утримання) залежно від тривалості стадії функціонування $T_{2}$.

Номограму оцінювання коефіцієнту динаміки вартості $k_{t \mathrm{i} 3}$ життєвого циклу базових компонентів носія спроможності на стадії розформування залежно тривалості цієї стадії наведено на рис.7. Так як стадія розформування носія спроможності не повинна перевищувати 5-10\% від тривалості загального його життєвого циклу, тоді доцільно зміну вартості носія спроможності від тривалості стадії розформування описати лінійною функцією. Тобто динаміка вартості носія спроможності на цій стадії має лінійний характер спадаючої функції, що обумовлено зменшенням організаційної структури або органу управління ЗС України 3 часом тривалості цієї стадії життєвого циклу (рис. 2). Коефіцієнт $k_{t \text { iз }}$ відображає зміну вартості життєвого циклу базових компонентів організаційної структуру або органу управління зС України на стадії розформування $T_{3}$ залежно від тривалості цієї стадії.

Номограму оцінювання коефіцієнту динаміки вартості $k_{t i 4}$ життєвого циклу базових компонентів носія спроможності ЗС України на стадії переформування залежно від тривалості цієї стадії наведено на рис. 8. Коефіцієнт $k_{t i 4}$ відображає зміну (динаміку) вартості життєвого циклу базових компонентів організаційної структуру або органу управління 3С України на стадії переформування залежно від тривалості стадії переформування $T_{4}$.

Досвід та попередні дослідження показують, що динаміка вартості носія спроможності ЗС України на стадії переформування може мати лінійний характер описаний лінійною зростаючою функцією (рис. 8, рис. 2), або нелінійний характер описаний спадаючою показниковою функцією (рис.9), що залежить від масштабу носія спроможності. У більшості випадків функція динаміки вартості носія спроможності на стадії переформування має лінійний характер, та дещо схожа з динамікою на стадії створення. Проте, якщо масштаб носія спроможності великий, тоді опису динаміки вартості носія спроможності на стадії переформування буде більш притаманна показникова функція (рис.9), бо тривалість переформування збільшується ізза поєднання у собі заходів стадій розформування та створення. 


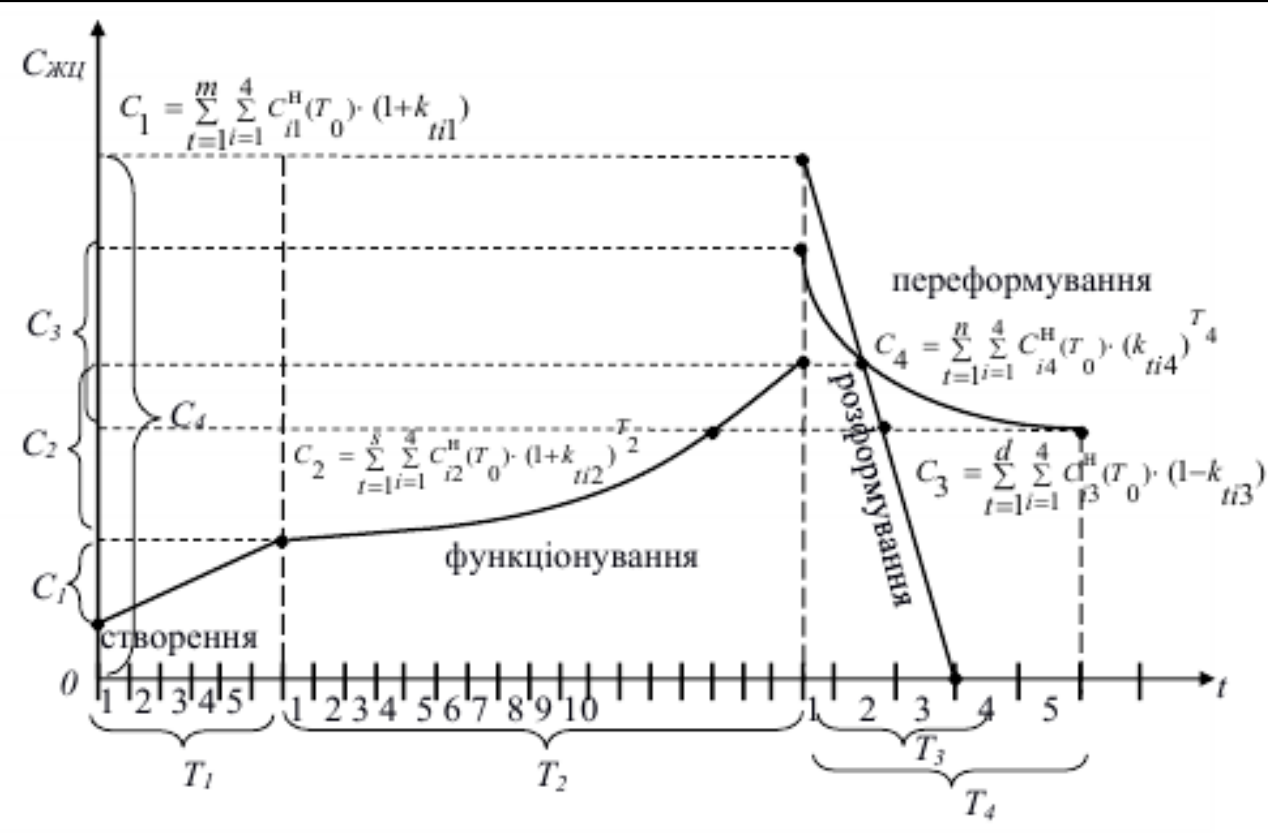

Рис. 9 - Залежність вартості життєвого циклу носіїв спроможностей (організаційних структур або органів управління) Збройних Сил України від тривалості стадій життєвого циклу

Четвертий етап - є узагальнюючим етапом, бо на ньому формується остаточна вартість життєвого циклу носіїв спроможностей 3 С України та тривалість їх життєвого циклу. Залежно від стадій життєвого циклу, загальна вартість життєвого циклу організаційних структур або органів управління носіїв спроможностей ЗС України розраховується так:

$$
\begin{gathered}
C_{Ж Ц}=C_{1}+C_{2}+C_{3} ; \\
C_{Ж Ц}=C_{1}+C_{2}+C_{4} ; \\
C_{Ж Ц}=C_{4}+C_{2}+C_{3} .
\end{gathered}
$$

При цьому, тривалість життєвого циклу визначається таким чином:

$$
\begin{gathered}
T_{\text {жц }}=T_{1}+T_{2}+T_{3} ; \\
T_{\text {жЦ }}=T_{1}+T_{2}+T_{4} ; \\
T_{\text {жц }}=T_{4}+T_{2}+T_{3} .
\end{gathered}
$$

Залежність вартості життєвого циклу організаційних структур або органів управління носіїв спроможностей ЗС України від тривалості стадій графічно представлено на рис. 9.

Якщо вартість життєвого циклу перевищує економічні можливості держави $\left(C_{ж ц} \leq C_{\text {мож }}\right)$, тоді необхідно приймати рішення щодо зміни тривалості стадій життєвого циклу або уточнити вхідні дані щодо подальшого розвитку носіїв спроможностей в програмах (планах).
Отже, у цілому вартість життєвого циклу організаційних структур або органів управління ЗС України залежить по-перше, від тривалості кожної стадії життєвого циклу; по-друге, від величини коефіцієнтів динаміки вартості у часі на кожній стадії життєвого циклу за базовими компонентами; по-третє, від початкової (базової) вартості носія спроможності ЗС України $C_{1}^{\mathrm{H}}\left(\mathrm{T}_{0}\right)$ в перший рік на кожній стадії життєвого циклу.

Одним із важливих факторів точності проведених розрахунків $\epsilon$ правильно визначені показники початкової (базової) вартості носія спроможності ЗС України $C_{1}^{\mathrm{H}}\left(\mathrm{T}_{0}\right)$ в перший рік кожної стадії життєвого циклу та величини коефіцієнтів динаміки вартості у часі на кожній стадії життєвого циклу за базовими компонентами.

Таким чином, представлений методичний підхід обґрунтування вартості життєвого циклу носіїв спроможностей ЗС України може бути основою для вирішення завдань оборонного планування та управління оборонними ресурсами щодо:

визначення вартості окремого носія спроможності ЗС України;

визначення вартості стадій життєвого циклу носія спроможності я ЗС України;

визначення повної прогнозованої вартості 
життєвого циклу носія спроможності ЗС України з метою оцінювання доцільності їх Висновки

Застосування

методичного підходу до обгрунтування вартості життєвого циклу носіїв спроможностей (організаційних структур та органів управління) ЗС України дозволить:

оперативно здійснювати розрахунки прогнозованої вартості життєвого циклу носіїв спроможностей ЗС України;

$$
\text { розраховувати вартість }
$$

носія спроможності 3С України за стадіями життєвого циклу за базовими елементами: озброєння та військова техніка, особовий склад, витратні матеріально-технічні засоби та елементи військової інфраструктури;

оцінювати доцільність створення нових або переформування існуючих організаційних структур та органів управління ЗС України шляхом порівняння прогнозованих вартісних показників життевого циклу носіїв спроможностей ЗС України з економічними можливостями держави щодо їх створення;

обгрунтовувати доцільні терміни створення, функціонування створення,

подальшого

розвитку, розформування або переформування. розформування (переформування) організаційних структур та органів управління зС України за економічним критерієм, тобто обґрунтовувати оптимальну тривалість кожної стадії життєвого циклу носіїв спроможностей ЗС України;

обгрунтовано корегувати програми та плани щодо розвитку спроможностей 3С України та тривалості стадій їх життєвого циклу;

обґрунтовано визначати потреби у фінансових ресурсах в програмах та планах розвитку ЗС України тощо.

Застосовувати даний підхід пропонується спеціалістам Міністерства оборони України та Генерального штабу 3С України під час прийняття рішень щодо формування варіантів переліку організаційних структур та органів управління ЗС України та визначення тривалості їх існування.

Подальші дослідження можуть бути пов'язані 3 розробленням програмного забезпечення для реалізації та запропонованого методичного підходу.

\section{Список використаних джерел}

1. Про затвердження Примірної методики визначення вартості життєвого циклу: наказ Міністерства розвитку економіки, торгівлі та сільського господарства України від 28.09. 2020 року № 1894 - URL: https://me.gov.ua/legislativeacts/Detail?lan $\mathrm{g}=u k-U A \& i d=32140 \mathrm{~d} 03-\mathrm{d} 5 \mathrm{eb}-4988-8790-$ 6d60d1c84a93

2. Директива 2014/24/€C Європейського Парламенту та Ради Європейського Союзу від 26 лютого 2014 року про державні закупівлі - URL: https://eurlex.europa.eu/eli/dir/2014/24/2018-01-01

3. Методичні рекомендації 3 фінансовоекономічного обґрунтування вартості повного життєвого циклу спроможностей 3 урахуванням принципів та стандартів НАTO: затверджені Міністром оборони України від 02.06.2020 - URL: https://www.mil.gov.ua/content/oboron_pl ans/metod_recom_z_fin_ekon_life_ciklu_na to.pdf

4. Про затвердження Порядку організації та здійснення оборонного планування в Міністерстві оборони України, Збройних Силах України та інших складових сил оборони: наказ Міністерства оборони України від 22.12.2020 № 484 - URL: https://zakon.rada.gov.ua/laws/show/z0196 $-21 \# \mathrm{n} 12$

5. Єдиний перелік (каталог) спроможностей Міністерства оборони України та Збройних Сил України : затв. Мін. оборони України 28.11.2017 р. 356 c.

6. Рекомендації з оборонного планування на основі спроможностей в Міністерстві оборони України та Збройних Силах України : затв. Міністром оборони України 
12.06.2017 p. 49 c.

7. Рекомендації 3 порядку організації проведення оцінювання спроможностей у Збройних Силах України: затв. Міністром оборони України 07.12.2017 р. 29 с.

8. Методичні рекомендації $з$ управління проєктами: затв. Міністром оборони України 20.02.2019 р. 52 с.

9. Методичні рекомендації з проведення оборонного огляду : затв. Міністром оборони України 07.06.2019 р. 84 с.

10. Доктрина 3 оборонного планування у Збройних Силах України, затверджена Головнокомандувачем Збройних Сил України 13.11.2020;

11. Збірка практик розрахунку вартості життєвого циклу, НАTO / Code of Practice for Life Cycle Costing, RTO-TR-SAS-069 // NATO Research Technology Organisation, System Analysis and Studies Panel, Task Group 069. September 2009. P. 64

12. Методи та моделі розрахунку вартості життєвого циклу, НATO / Methods and Models for Life Cycle Costing, RTO-SAS-054 // Final Report of Task Group Technical Report SAS-054. June 2007. P. 226

13. Cost Structure and Life Cycle Costs for Military Systems / RTO TR-058 SAS-028 // Task Group Technical Report. September 2003. P. 104.

14. NATO Standard AAP-20 / NATO Programme Management Framework (NATO Life Cycle Model)// Edition C Version 1 October 2015. P. 78.

15. NATO Standard AAP-48 / NATO System Life Cycle Processes // Edition B Version 1 Mars 2013. P. 68.

16. Зварич А. О., Чернишова І. М., Середюк С. А. Удосконалена методика визначення вартості підтримання та розвитку носіїв спроможності (військових організаційних структур) // Зб. наук. пр. ЦНДІ ЗС України. Київ: 2020. № 3 (94). С. 119-131.

\title{
Методический подход к обоснованию стоимости жизненного цикла носителя возможностей Вооруженных сил Украины (организационных структур и органов управления)
}

\author{
Олег Семененко * 1 А; Ирина Чернышева 2 А; Петр Онофрийчук ${ }^{3}$ А; \\ Иван Мотрунич 4 в; Константин Харитонов 5 в; Роман Демчук 6 C \\ Corresponding author: ${ }^{1}$ д.в.н., с.н.с., начальник отдела, e-mail: aosemenenko@ukr.net, ORCID: 0000-0001-6477-3414 \\ ${ }^{2}$ к. військ. н., с.н.с., e-mail: aosemenenko@ukr.net, ORCID: 0000-0002-5958-7059 \\ ${ }^{3}$ кандидат экономических наук, старший научный сотрудник, e-mail: aosemenenko@ukr.net, ORCID: 0000-0003-2203-5282 \\ ${ }^{4}$ e-mail: aosemenenko@ukr.net, ORCID: 0000-0001-6117-1784 \\ ${ }^{5}$ соискатель ученой степени, e-mail: kvharitonov.1212@gmail.com, ORCID: 0000-0002-5236-0556 \\ ${ }^{6}$ e-mail: aosemenenko@ukr.net, ORCID: 0000-0003-0354-0371
}

А Центральный научно-исследовательский институт Вооруженных Сил Украины, пр-кт Воздухофлотский 28 г. Киев, 03049, Украина в Генеральный штаб Вооруженных Сил Украины, пр-кт Воздухофлотский, 6, г. Киев, 03168, Украина

с Национальный университет обороны Украины имени Ивана Черняховского, пр-кт Воздухофлотский, 28, г. Киев, 03049, Украина

\begin{abstract}
Аннотация
Зміни характеру сучасних воєнних конфліктів, збільшення зовнішніх загроз, зміни економічних та військово-технічних умов розвитку України впливають на діапазон та зміст завдань, до виконання яких залучаються Збройних Сил (3С) України. Зазначене обумовлює пошук нових підходів до планування розвитку 3С України та створюють передумови для необхідності удосконалення існуючої системи оборонного планування в Україні взагалі. Одним зі шляхів забезпечення ефективного функціонування сучасної системи оборонного планування України вважається запровадження методу планування на основі спроможностей та обґрунтування витрат з використанням поняття вартості життєвого циклу. У статті авторами запропонований методичний підхід до обґрунтування вартості життєвого циклу носіїв спроможностей ЗС України (організаційних структур та органів
\end{abstract}


управління). Обгрунтування вартості організаційних структур та органів управління 3С України із застосування поняття вартості їх життєвого циклу надасть можливість підвищити достовірність розрахунків щодо очікуваного результату заходів розвитку спроможностей ЗС України та обсягів необхідних фінансових ресурсів на потреби їх розвитку. Застосовувати даний підхід пропонується спеціалістам Міністерства оборони України та Генерального штабу ЗС України під час прийнятя рішень щодо формування варіантів переліку організаційних структур та органів управління ЗС України та визначення тривалості їх існування. Запропонований методичний підхід обґрунтування вартості життєого циклу носіїв спроможностей зС України може бути основою для вирішення завдань оборонного планування та управління оборонними ресурсами щодо: визначення вартості окремого носія спроможності ЗС України; визначення вартості стадій життєвого циклу носія спроможності ЗС України; визначення повної прогнозованої вартості життєвого циклу носія спроможності ЗС України з метою оцінювання доцільності їх створення, подальшого розвитку, розформування або переформування.

Ключевые слова: жизненный цикл, затраты, способность, ресурсы, планирование.

\title{
Methodical approach to account of life cycle cost of capabilities of Armed forces of Ukraine (organizational structures and governing bodies)
}

\author{
Oleh Semenenko * 1 A; Iryna Chernyshova ${ }^{2}$; Petro Onofriychuk ${ }^{3}$ A; \\ Ivan Motrunych ${ }^{4} \mathrm{~B}$; Konstantin Kharitonov ${ }^{5}$; ; Roman Demchuk ${ }^{6 C}$ \\ Corresponding author: ${ }^{1}$ Dr of military sciences, Senior Research Fellow, Head of Department, e-mail: aosemenenko@ukr.net, ORCID: 0000-0001-6477-3414 \\ 2 Ph.D., Senior Researcher, e-mail: aosemenenko@ukr.net, ORCID: 0000-0002-5958-7059 \\ ${ }^{3}$ Ph.D., e-mail: aosemenenko@ukr.net, ORCID: 0000-0003-2203-5282 \\ ${ }^{4}$ Ph.D., student, e-mail: aosemenenko@ukr.net, ORCID: 0000-0001-6117-1784 \\ ${ }^{5}$ Ph.D., student, e-mail: kvharitonov.1212@gmail.com, ORCID: 0000-0002-5236-0556 \\ ${ }^{6}$ e-mail: aosemenenko@ukr.net, ORCID: 0000-0003-0354-0371 \\ A Central Research Institute of Armaments and Military Equipment Armed Forces of Ukraine, 28, Povitroflotsky, ave, Kyiv, 03049, Ukraine \\ ${ }^{B}$ General Staff of the Armed Forces of Ukraine, 6, Povitroflotskyi Ave., Kyiv, 03168, Ukraine \\ c National Defence University of Ukraine named after Ivan Cherniachovskyi, 28, Povitroflotsky, ave, Kyiv, 03049, Ukraine
}

\begin{abstract}
Changes in the character of modern military conflicts, increasing external threats, changes in economic and military-technical conditions of Ukraine's development affect the range and content of tasks to which the Armed Forces (AF) of Ukraine are involved. This determines the search for new approaches to planning the development of the Armed Forces of Ukraine and creates the preconditions for the need to improve the existing system of defense planning in Ukraine in general. One of the ways to ensure the effective functioning of the modern defense planning system of Ukraine is the introduction of a method of planning based on capabilities and justification of costs using the concept of life cycle cost. In the article the authors propose a methodical approach to substantiating the cost of the life cycle of carriers of capabilities of the Armed Forces of Ukraine (organizational structures and governing bodies). Substantiation of the cost of organizational structures and governing bodies of the Armed Forces of Ukraine on the application of the concept of cost of their life cycle will increase the reliability of calculations on the expected result of measures to develop the capabilities of the Armed Forces of Ukraine and the necessary financial resources for their development. Specialists of the Ministry of Defense of Ukraine and the General Staff of the Armed Forces of Ukraine are invited to apply this approach when making decisions on forming options for the list of organizational structures and governing bodies of the Armed Forces of Ukraine and determining the duration of their existence. The proposed methodological approach to substantiate the value of the life cycle of carriers of capabilities of the Armed Forces of Ukraine can be the basis for solving problems of defense planning and management of defense resources to: determine the cost of a single
\end{abstract}


carrier of capabilities of the Armed Forces of Ukraine; determining the cost of the stages of the life cycle of the carrier of the capability of the Armed Forces of Ukraine; determination of the full projected cost of the life cycle of the carrier of the Armed Forces of Ukraine in order to assess the feasibility of their creation, further development, disbandment or reformulation.

Keywords: life cycle, costs, capacity, resources, planning.

\section{References}

1. Nakaz Ministerstva rozvytku ekonomiky, torhivli ta sil's'koho hospodarstva Ukrayiny № 1894 vid 28. 09. 2020 roku "Pro zatverdzhennya Prymirnoyi metodyky vyznachennya vartosti zhyttyevoho tsyklu" [Order of the Ministry of Development of Economy, Trade and Agriculture of Ukraine № 1894 of September 28, 2020 “On approval of the Model methodology for determining the value of the life cycle"] Available from: https://me.gov.ua/legislativeacts/Detail?lan $\mathrm{g}=u k-U A \& i d=32140 \mathrm{d03}-\mathrm{d} 5 \mathrm{eb}-4988-8790-$ 6d60d1c84a93

2. Dyrektyva 2014/24 /YES Yevropeys'koho Parlamentu ta Rady Yevropeys'koho Soyuzu vid 26 lyutoho 2014 roku pro derzhavni zakupivli [Directive 2014/24 / EU of the European Parliament and of the Council of 26 February 2014 on public procurement] Available from: https://eurlex.europa.eu/eli/dir/2014/24/2018-01-01

3. Metodychni rekomendatsiyi $z$ finansovoekonomichnoho obgruntuvannya vartosti povnoho zhyttyevoho tsyklu spromozhnostey z urakhuvannyam pryntsypiv ta standartiv NATO zatverdzheni Ministrom oborony Ukrayiny vid 02.06.2020 [Methodical recommendations on financial and economic substantiation of the cost of the full life cycle of capabilities, taking into account NATO principles and standards, were approved by the Minister of Defense of Ukraine on 02.06.2020] Available from: https://www.mil.gov.ua/content/oboron_pl ans/metod_recom_z_fin_ekon_life_ciklu_na to.pdf

4. Nakaz Ministerstva oborony Ukrayiny № 484 vid 22.12.2020 "Pro zatverdzhennya Poryadku orhanizatsiyi ta zdiysnennya oboronnoho planuvannya $v$ Ministerstvi oborony Ukrayiny, Zbroynykh Sylakh
Ukrayiny ta inshykh skladovykh syl oborony" [Order of the Ministry of Defense of Ukraine № 484 of 22.12.2020 "On approval of the Procedure for organization and implementation of defense planning in the Ministry of Defense of Ukraine, the Armed Forces of Ukraine and other components of the Defense Forces"] Available from: https://zakon.rada.gov.ua/laws/show/z0196 $-21 \# n 12$

5. Yedynyy perelik (kataloh) spromozhnostey Ministerstva oborony Ukrayiny ta Zbroynykh Syl Ukrayiny : zatv. Min. oborony Ukrayiny 28.11.2017 . 356 p. [Unified list (catalog) of capabilities of the Ministry of Defense of Ukraine and the Armed Forces of Ukraine: approved. Min. of Defense of Ukraine 11/28/2017]

6. Rekomendatsiyi z oboronnoho planuvannya na osnovi spromozhnostey $v$ Ministerstvi oborony Ukrayiny ta Zbroynykh Sylakh Ukrayiny : zatv. Ministrom oborony Ukrayiny 12.06.2017 y. 49 p. [Recommendations on capability-based defense planning in the Ministry of Defense of Ukraine and the Armed Forces of Ukraine: approved. Minister of Defense of Ukraine 06/12/2017]

7. Rekomendatsiyi z poryadku orhanizatsiyi provedennya otsinyuvannya spromozhnostey u Zbroynykh Sylakh Ukrayiny: zatv. Ministrom oborony Ukrayiny 07.12.2017 y. 29 c. [Recommendations on the organization of capability assessment in the Armed Forces of Ukraine: approved. Minister of Defense of Ukraine 12/07/2017]

8. Metodychni rekomendatsiyi shchodo upravlinnya proektamy: zatverd. Ministr oborony Ukrayiny 20 lyutoho 2019 y. 52 c. [Methodical recommendations for project management: approved. Minister of Defense of Ukraine on February 20, 2019] 
9. Metodychni rekomendatsiyi z provedennya oboronnoho ohlyadu : zatv. Ministrom oborony Ukrayiny 07.06.2019 y. 84 p. [Methodical recommendations for conducting a defense review: approved. Minister of Defense of Ukraine 06/07/2019]

10. Doktryna z oboronnoho planuvannya u Zbroynykh Sylakh Ukrayiny, zatverdzhena Holovnokomanduvachem Zbroynykh Syl Ukrayiny 13.11.2020 [Doctrine on defense planning in the Armed Forces of Ukraine, approved by the Commander-in-Chief of the Armed Forces of Ukraine 11/13/2020]

11. Code of Practice for Life Cycle Costing, RTOTR-SAS-069 // NATO Research Technology Organisation, System Analysis and Studies Panel, Task Group 069. September 2009. P. 64

12. Methods and Models for Life Cycle Costing, RTO-SAS-054 // Final Report of Task Group Technical Report SAS-054. June 2007. P. 226

13. Cost Structure and Life Cycle Costs for
Military Systems / RTO TR-058 SAS-028 // Task Group Technical Report. September 2003. P. 104.

14. NATO Standard AAP-20 / NATO Programme Management Framework (NATO Life Cycle Model) // Edition C Version 1 October 2015. P. 78.

15. NATO Standard AAP-48 / NATO System Life Cycle Processes // Edition B Version 1 Mars 2013. P. 68.

16. Zvarich A. O., Chernyshova I. M., Seredyuk S. A. Udoskonalena metodyka vyznachennya vartosti pidtrymannya ta rozvytku nosiyiv spromozhnosti (viys'kovykh orhanizatsiynykh struktur) [Improved methodology for determining the cost of maintaining and developing capacity carriers (military organizational structures)] // Collection of scientific works of the Central Research Institute of the Armed Forces of Ukraine. Kiev: 2020. № 3 (94). P. 119-131. 